\title{
EXUBERANT AS TREND FORECAST METHOD FOR KERTABUMI KLINIK SAMPAH COMMUNITY PLASTIC RECYCLING
}

\author{
${ }^{1}$ Siti Chadijah, ${ }^{2}$ Fauzia Latif, ${ }^{3}$ Reno Fanthi \\ Interior Design Program, School of Design, Bina Nusantara University \\ ${ }^{1}$ siti.chadijah@binus.ac.id \\ ${ }^{2}$ fauzia.latif@binus.ac.id \\ ${ }^{3}$ rfanthi@binus.ac.id
}

Received: July $17^{\text {th }}, 2020 /$ Revised: August $21^{\text {th }} 2020 /$ Accepted: September $18^{\text {th }}, 2020$

\begin{abstract}
Recycling movement is such a never- ending campaign. This movement are grown larger in the society whether in individual or group activities. Any of the groups with the same spirit and vision are blurred in the community to achieve wider impact of recycling plastic. One of the active campaigner is Kertabumi Klinik Sampah which well-known in tinkering any of the recycling technique within the communities around Jakarta. Communities under Kertabumi facilitation are encouraged to turned plastic waste into unique and valuable products. Fostering creativity is the idea of this research aiming to observe the possibility of trend design implementation on the plastic recycle product. Exuberant trend forecasting is used as an approach to designing functional and aesthetical aspect on the product. Moreover, the styling result is offered as a design recommendation for the community to develop their product in the future.
\end{abstract}

Keywords: Exuberant, Design Trend, Recycling Product, Community, Kertabumi Klinik Sampah

\section{Introduction}

Recycled material has been used as industrial product and craft for years. Many of the materials are using domestic waste such as organic material, broken gadgets, and plastic waste to be processed in communities or home industry scale to empowering the society. Specific method and manual techniques are used by the communities to produce craft for their typical enthusiasts and customers. As time goes by, recycle product enthusiasts are gradually increasing as $80 \%$ the factor of customer decision to buy recycled product was based on the quality and design variable (Wibisono.2018). This might reinforce the mission of recycling along with added value in economical and design aspect. This opportunity is potentially supporting the communities to be focused on producing craft using the waste as the main materials.

Used plastic waste and electronic waste such as charging cable and broken headset are used to be the main resources that are explored in this research. Plastic waste materials that are commonly produced in domestic waste identified as HDPE (High Density Polyethylene) and PET (Polyethylene Terephthalate). These type of plastic are included in the biggest pollutant on the environment indexed approximately $16 \%$ from the collected sample on Jakarta water flow, with the highest rate contributed by the single - use plastic bags (World Bank Group. 2018). Those findings were illustrated the treatments for the plastic waste are still low in neither quantities nor qualities. Meanwhile, electronic 
cables that usually find in our mobile phone or electronic gears are also another problematic waste as B3 category. This type of waste is including in the group of highly dangerous potential caused by the complexity of the component and difficulty to be decomposed when ended up on the landfill and polluting the soil.

Responding those issues, Kertabumi Klinik Sampah, which has been working in the environmental and recycling activities is a community - based social enterprises since 2017. These activities are supporting sustainable living towards managing the garbage in creative way. Kertabumi Klinik Sampah also works with several communities around Jakarta. Some of the product development has been related to certain material and brands with the simple technique but were able to achieve maximum explorations. Therefore, this research aims to foster the potential development of plastic and electronic waste furthermore. By the simple techniques and tools gathered with the ability of the community itself, this development is trying to find novelty in recycling waste into a functional product.

This research is conducted by the literature study and match trend forecast guidance in Singularity ( 2019-2020 guidance year) for the interior decoration product . Firstly, this research is collecting data to the selected trend forecasting to be matched with the available resources, such as plastic and electronic waste. Secondly, the trend guidance has become the guidance for the product creation comprises functional, visual and form development. The result of this research will become a material development recommendation for the communities under Kertabumi Klinik Sampah facilitation.

\section{Result and Discussion}

In the community and home industry scale, trend predicting and styling have never been a primary issue. Oftentimes, this step was using image or another product as a reference, then the community will produce with their capacity to fulfil the customer requests. Indonesia Trend Forecasting ( ITF) through Badan Ekonomi Kreatif Republik Indonesia (Bekraf RI) which now has been transformed into Kementrian Pariwisata dan Ekonomi Kreatif Republik Indonesia ( Kemenparekraf RI) has been released their research report. The research is conducting trend research which is reviewing several projections of market tendency based on the phenomenon of the current situation. (Singularity.2019). The method of trend forecasting usually reviewed every year or until 8 months prior to the targeted year to come. On the projection there are 4 themes which describing the trend prediction for 2019-2020 period; Exuberant, Svarga, Cortex, and Neo- Medieval.

Exuberant, as one of the trend prediction that is referring to the emergence of the subculture reflecting Asian lifestyles which are spreading over the United State of America (Western lifestyle) and all around the globe. Merriam - Webster dictionary describe Exuberant as a happy, full of energy, and enthusiasm feeling or condition. Trend Forecasting report book also said that basic character of Exuberant is demonstrating amusement and optimism along with the playful, friendly, stylish, and have a "nerdy" and funny look. This styling is also combining the digital technique and "comic- like" graphic style, cartoon, and street - art colour. Exuberant has several sub trends; Posh Nerd, Urban Caricature, Friendly Bot, and New Age Zen. Each of the sub trends are illustrating specific characteristic from the Exuberant expression as a style and trend guidance. 

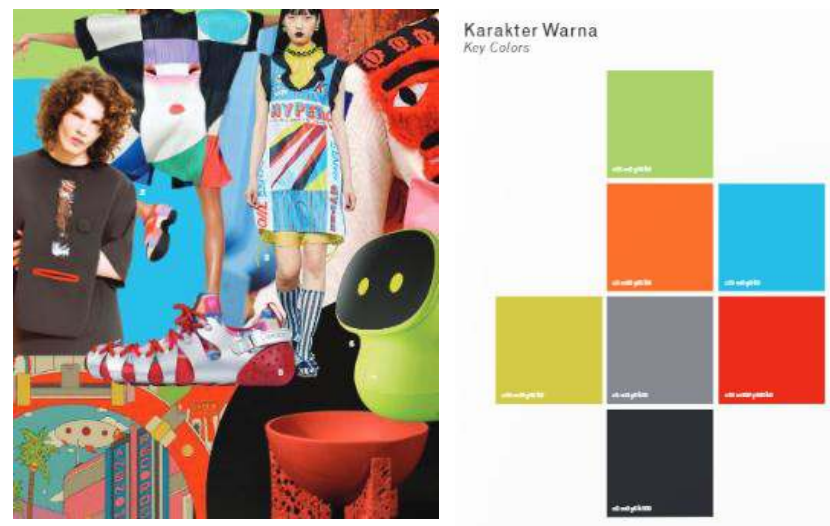

Image 1. Trend Guidance Containing Color, form, and patern of Exuberant ( ITF Team .2018)

Exuberant trend guidance has taken on this study case is considering the congruency of the waste materials and the characteristic of the Exuberant with their vibrant colour, as the colours of street arts. Besides, the flexibility and elasticity of the waste materials is enabling the further exploration with the caricature form which are describing friendliness, simplicity, and fun.

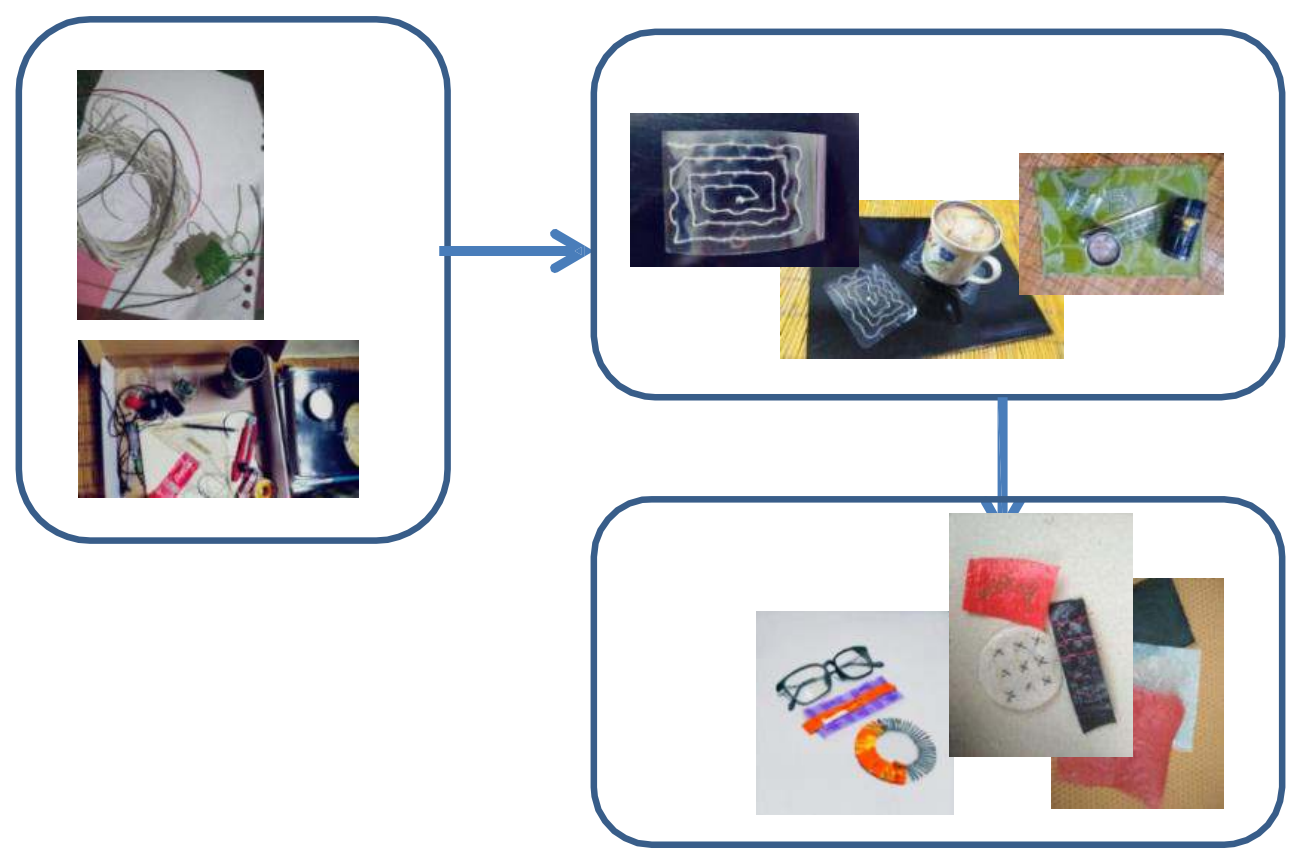

Image 2. The result of waste materials exploration (Author.2020)

On the exploration process, heat press technique is used to gain the compact sheet form of the single- use plastic bag. Single - use plastics are able to be recycled by heat processing. The simple technique was adapted from the Global Fusion which apply pressure along with heat to fuse plastic into a sheet with an electric iron and piece of paper (Deshpande.2019). The paper is used to support the 
pressure and heating process evenly without burning the plastic bag sheet. This plastic sheet is developed to be the product basic material with various dimensions according to the material requirement of the product. Meanwhile, stitching technique which usually used in the sewing techniques is explored to insert the electronic cable to the plastic sheet. The stitching pattern produce abstract caricature form which adopting the basic form, such as plus (+), minus (-), standard stitching pattern, or other explorative pattern. This pattern is made to give contrast and attractive visual appearance.

Author team explored the possibility of production on the used plastic packaging and plastic straw paired with the waste electronic cable from the charging cable and broken headset to be a coaster and eyeglasses sleeve. On this experiment, the author team try to innovate in the form of visual and technique that never been tried before by the community. The community can have a new way to treat the plastic and electronic waste along with new technique and visual result.
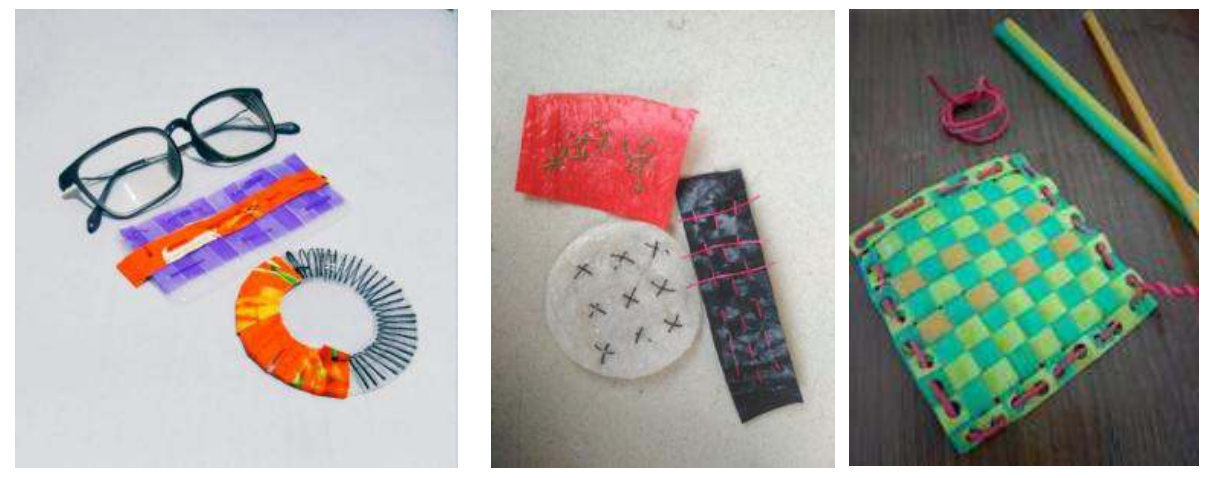

Image 3. Product Result for Interior Decoration and Lifestyle ( Author Team . 2020)

\section{Conclusion}

Innovation on the recycled based product for the community and home industry scale are able to be achieved by using the trend prediction and forecasting approach. Visual approach to match the available material resources and the trend characteristic are potentially developed to various interior or lifestyle products, as for the material knowledge transfer of this research to the community has been done by the online tutorial video. The video link can be tested by the community member individually so that the workshops able to be done sustainably in any conditions. Product innovation could stimulate creativity and variation of the product so that the community can improve their quality on offering product with novelty and other added value 


\section{References}

World Bank Group. 2018. Indonesia Debris Marine Hotspot, Rapid Assesment - Synthesis Report.

Deshpande, H., Akash T., Posner, N., Oh. H. 2019. Heat-Based Fabrication Techniques for Upcycling HDPE Plastic Bags. CoDeCraft Lab Georgia Tech Project Research. Retrieved from https://gvu.gatech.edu

https://www.qualitylogoproducts.com/promo-university/different-types-of-plastic.htm

Indonesia Trend Forecasting Team. 2019. Singularity: INTERIOR Design \& DÉCOR. Badan Ekonomi Kreatif Indonesia. Retrieved from http://trendforecasting.id/singularity- section/book-interior-decor-3 2019

Wibisono, S.S. 2018. Analisis Faktor Keputusan Konsumen Produk Daur Ulang. Universitas Islam Indonesia: Yogyakarta. 